\title{
The Effect of Oil Price Shocks on the Saudi Manufacturing Sector
}

\author{
Abdelhamid A. Mahboub \\ University of Business and Technology, Jeddah, Saudi Arabia \\ Heba E. Ahmed \\ Qassim University, Qassim, Saudi Arabia
}

\begin{abstract}
This paper aims to examine the effects of oil price shocks on the manufacturing sector in Saudi Arabia during the period 2002-2014, using quarterly data. The paper has conducted a unit root test. The data are shown to be non-stationary in the level, and they became stationary in the first difference for all variables. The co-integration model was applied, and the results indicated that no co-integrating equation exists, which means that there is no long run effect of oil price shocks on the manufacturing sector. Therefore, the paper estimated a VAR model, the results of which implied that oil price shocks do not affect the manufacturing sector in the short run, and it may have an effect on the manufacturing sector after 10 quarters according to the Impulse Response Function. The recent fall of oil prices since June 2014 is just one round of a series of fluctuations, in the form of shocks, in oil prices. Nevertheless, a debate has arisen about the effect of this price falls on the world economy in general and on oil exporting countries in particular. The economy of Saudi Arabia, the major oil exporting country, is not an exception in this matter of course. The main objective of this paper is to estimate quantitatively, in the economy of Saudi Arabia, whether there exists an impact of oil price shockson the output of the manufacturing sector, and whether it is a positive (direct) or a negative (inverse) relationship. The focus on the manufacturing sector here is for two reasons. First, the Saudi economic planning and policy have long targeted to diversify the sources of generating GDP. The manufacturing sector is, no doubt, a very important element in this diversification process. Second, the increase in manufacturing sector (as a percentage of GDP) is one of the important measures and/or indicators of economic development. For both reasons, the researchers have chosen to study "the effect of oil price shocks on the Saudi manufacturing sector" in this paper.
\end{abstract}

Keywords: oil prices, Saudi manufacturing output, VAR, impulse response function

\section{Theoretical Background and Related Literature}

Theoretically, the change in oil prices is expected to have two contradictory effects on the manufacturing sector. For example, the fall in oil prices, given that energy is an essential input to manufacturing industries (especially petrochemicals, which commonly represent a major industrial subsector in most oil rich countries),

\footnotetext{
Abdelhamid A. Mahboub, professor, the College of Business Administration, University of Business and Technology, Jeddah, Saudi Arabia.

Heba E. Ahmed, Ph.D., lecturer, the College of Business and Economics, Qassim University, Qassim, Saudi Arabia.

Correspondence concerning this article should be addressed to Heba E. Ahmed, the College of Business and Economics, Qassim University, Qassim, 6666, Buraidah 51452, Saudi Arabia.
} 
will reduce the cost of production. This may very well induce manufacturing output. Many researchers have emphasized this effect. Alper and Torul (2009) have studied this relationship in the Turkish economy, using the Vector Auto Regressive (VAR) Model for Turkish 1988-2006 data, and found that while oil price increases did not significantly affect the manufacturingsector in aggregate terms, some sub-sectors are adversely affected. Guidi (2015) has done a similar exercise on the UK economy, applying the VAR model for the 1970-2006 data. He found that the positive oil price changes resulted in a consistent contraction in manufacturing output, while the services sector did not seem to be affected by these increases in oil prices. As for Fukunaga, Hirakata, and Sudo (2010), who studied the issue in the US and Japan economies at industry level, they have found that the way oil price changes affects each industry depending on what kind of underlying shock drives oil price changes, as well as on industry characteristics, i.e., whether the industry is oil-intensive industry or not. Again, the inverse effect of oil price changes on industrial output appeared in most of the cases with different degrees. These preceding examples emphasize the role of oil as affecting the cost of production and hence the industrial total product.

However, in the case of Saudi Arabia, where the government plays an important role in supporting domestic industrial firms, the lower oil price will reduce oil export revenues (given the inelastic demand for oil). The government may not be able to provide the same level of support to domestic industry as it used to do. El Anshasy and Bradley (2011), Dizaji (2014), Garkaz, Azma, and Jafari (2012), and Hamdi and Sbia (2013) among other researchers, have expressed the same results that a fall in oil prices reduces government expenditure in oil exporting countries. However, in the context of Saudi Arabia, some writers referred to the fact that the country has accumulated enough reserves as a buffer stock against unexpected drop in oil prices and revenues. This should reduce the effects on domestic industrial firms. Therefore, one may expect, according to this line of thinking that the manufacturing sector in Saudi economy will not significantly suffer from the oil price changes via the cost of production as long as the government is subsidizing the price. Whitley and Makhijani (2014) have reported this observation. Accordingly, the effect of oil price shocks on manufacturing output may occur only through the effect on the government expenditures.

The above discussion shows that the net effect of oil price falling on the manufacturing sector is uncertain. The two contradictory effects apply also to the case of an increase in oil prices but in the opposite directions, and the net effect is again uncertain. Therefore, there is a need for an empirical research to estimate and test this relationship. This paper tends to do the job in the context of the Saudi Economy.

\section{Research Hypothesis}

This paper plans to test the following hypothesis: The oil price shocks have a significantly inverse effect on the output of the manufacturing sector in Saudi Arabia.

In the following sections, the paper will shed the light on the Saudi manufacturing sector and review the changes in oil prices. After this, it will provide the estimated model and the results of the estimation.

\section{Manufacturing Sector in Saudi Economy}

Manufacturing sector in the Saudi economy is growing continuously since there has been a realization of the importance of diversifying the economy. Growth of the manufacturing sector is expected to be in the heart of this diversification process. Besides, the relative share of manufacturing sector in GDP is one of the important measures and/or indicators of economic development. Specifically, the relative share of manufacturing sector in generating GDP is expected to increase in the course of economic development. 
During the period considered in this paper, the annual growth rate of the manufacturing output has increased from $3.4 \%$ in 2002 , jumped to $13.5 \%$ in 2004 , and stayed around $7 \%$ and $10 \%$ in the remaining period.

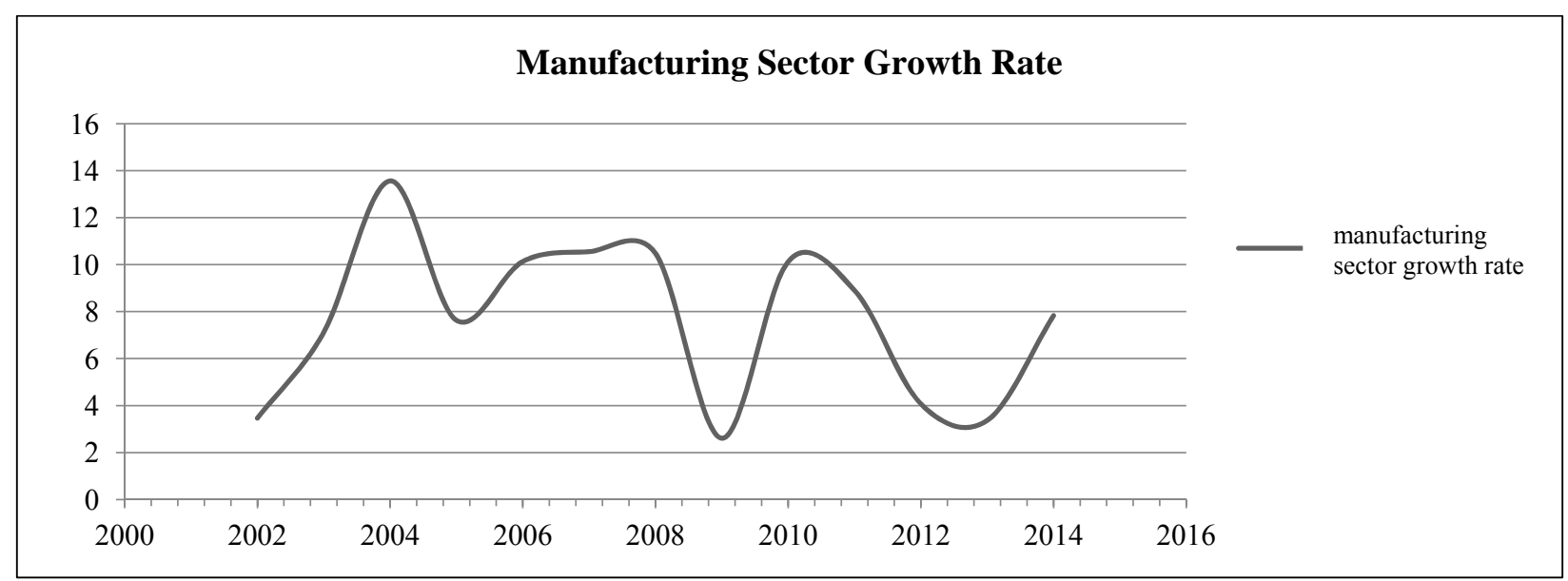

Figure 1. Manufacturing sector growth rate. Source: World Development Indicators, several issues.

The two giant existing industrial complexes, SABIC and Saudi ARAMCO are already producing plastics and petrochemical products and they are heading towards the production of aluminum. Saudi Arabia isendowed by two ingredients needed to produce aluminum: bauxite ore and cheap electricity. Hence, the country aims at developing the aluminum industry into the production of car parts and even fully assembled cars (The Economist, 3rd, January 2015). Besides, there is already an investment-spending plan of more than $\$ 70$ billion in building up six new "economic cities" with modern infrastructure and business-friendly regulations.

Transforming the economy into industrialization is not an easy journey, especially with the existence of oil export revenues that tend to delay the incentive for such transformation. During the years covered by this study, the manufacturing output as a percentage of GDP was around $10 \%$ to $13 \%$ (SAMA, several issues). Similarly, the exports of manufacture as percentage of merchandise exports were running between $7 \%$ and $11 \%$, as appeared in Table 1, which supports the previous remark that industrialization was slower than it should have been for several years because of the high oil export revenues.

Table 1

Manufacturing Sector Growth Rate

\begin{tabular}{llllllll}
\hline Year & 2000 & 2001 & 2002 & 2003 & 2004 & 2005 & 2006 \\
\hline$\%$ & 7.1 & 9.8 & 9.6 & 10.4 & 9.3 & 8.1 & 8.0 \\
Year & 2007 & 2008 & 2009 & 2010 & 2011 & 2012 & 2013 \\
$\%$ & 8.7 & 6.0 & 8.1 & 11.1 & 10.3 & 10.5 & 11.2 \\
\hline
\end{tabular}

Source: World Development Indicators, World Bank, Years 2002-2015.

\section{Changes in Oil Prices}

World oil prices were always subject to changes. The world market forces, no doubt, are responsible for these changes. However, since there exist a few big sellers and a few big buyers, the outcome of interaction among them does not necessarily agree with the traditional supply and demand model. During the years considered in this paper, oil price increased from $\$ 28.1$ per barrel in 2003 to the highest level of $\$ 109.45$ per barrel in 2012 and then back to $\$ 26.94$ per barrel in 2016. Figure 2 summarizes these movements in oil prices. 


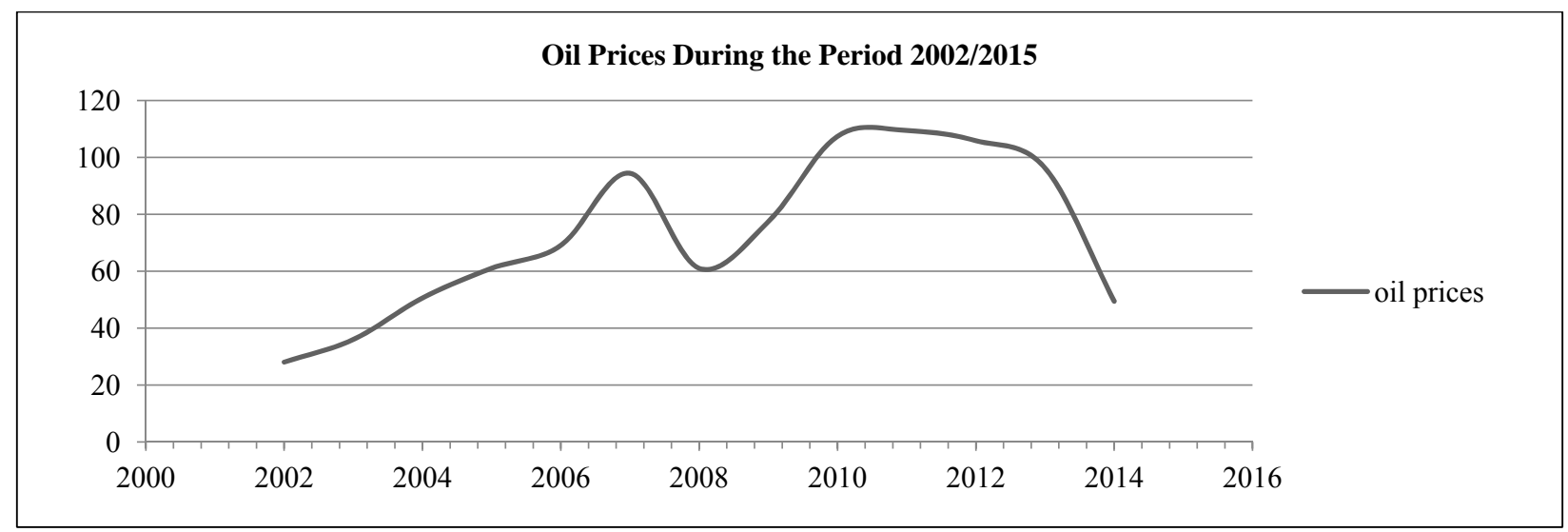

Figure 2. Oil price changes. Source: World Development Indicators WDI, World Bank, Years 2002-2015.

The low value of the price elasticity of international demand for oil results in similar movements (in direction) in export revenues, and in the Saudi economy this is very true.

\section{The Research Model and Estimation}

As expected, the manufacturing output can be affected by many other variables besides the oil prices. One needs to include these variables when assessing the relationship between oil prices and manufacturing output. Government subsidies have already been mentioned before in their effects on domestic industrial output (in the literature review). Besides, the government expenditures in general represent a significant component of domestic demand for manufacturing products. In addition, when these products are exportable, the exchange rate must be considered as well in the analysis.

In order to test the paper's hypothesis, the researchers will use the Vector Auto Regressive (VAR) model to estimate the relationship between oil price changes and the manufacturing sector output in Saudi Arabia. The data set, for each variable included in the model, consists of quarterly observations for the period Q1, 2002 to Q4, 2014. The source of data comes from World Development Indicators, WDI reports. The paper uses the EVIEWS package for estimation and hypothesis testing purposes.

The focus of the study is to estimate the relationship between oil price shocks and manufacturing sector product. The model used, contains five variables, namely manufacturing sector product, the oil price, the government expenditure, the real exchange rate, and the industrial exports. The basic equation of the model takes the following logarithmic form.

$$
\text { Ln Manufat } t=\text { c }+ \text { Ln Oil_price }{ }_{t}+\text { Ln Gov }{ }_{t}+\text { Ln Real_exch }+ \text { Ln Export } t+\varepsilon_{t}
$$

where:

- $\mathrm{Ln}$ is the natural log of the variable that follows it.

- The subscript $t$ refers to time index (the quarter of the year).

- Manufat is the manufacturing sector output or value added (\% of GDP).

- Oil_price is the oil price in dollars per barrel.

- Gov is the government expenditure (\% of GDP).

- Real_exch is the index of real effective exchange rate.

- Export is the industrial exports (\% the total exports of goods and services).

- Besides, $\mathrm{c}$ is the constant and $\varepsilon$ is the error term. 


\section{Unit Root Test}

The first step in using the time series data is to test the stationarity property of each variable. The paper uses the Augmented Dickey-Fuller (ADF) test for this purpose. For each variable, it considers the equation below:

$$
\Delta Y_{t}=\alpha_{0}+\gamma Y_{t-1}+\sum_{i=2}^{p} \psi_{i} \Delta Y_{t-i+1}+\varepsilon_{t}
$$

where $\mathrm{Y}$ is the variable of interest, $\Delta$ is the change, $\mathrm{t}$ is the time trend, $\mathrm{p}$ is the number of time lags, and $\boldsymbol{\varepsilon}_{\boldsymbol{t}}$ is the white noise residual with zero mean and constant variance. The parameters $\alpha_{0} \gamma$ and $\psi_{\mathrm{i}}$ are to be estimated. If the parameters are significant, one rejects the null hypothesis and there is no unit root. The data series for the concerned variable is stationary.

Table 2 shows the results of the Augmented Dickey-Fuller (ADF) for the time series data of the five model variables.

Table 2

Augmented Dicky Fuller Test Results

\begin{tabular}{lllll}
\hline Variables & \multicolumn{3}{c}{ Level } & 1st Difference \\
\cline { 2 - 5 } & Intercept & Intercept \& trend & Intercept & Intercept \& trend \\
\hline Oil_price & 1.63 & 2.22 & $6.83^{* * *}$ & $6.86^{* * *}$ \\
Real_exch & 2.9 & 1.9 & $7.06^{* * *}$ & $8.09^{* * *}$ \\
Manufat & 2.74 & 2.35 & $5.69^{* * *}$ & $5.44^{* * *}$ \\
Export & 1.58 & 1.95 & $6.90^{* * *}$ & $6.93^{* * *}$ \\
Gov & 1.9 & 2.27 & $6.93^{* * *}$ & $6.99^{* * *}$ \\
\hline
\end{tabular}

Note. $(*),(* *)$, and $(* * *)$ indicate the rejection of the null hypothesis of non-stationary at $10 \%, 5 \%$, and $1 \%$ significance level.

As shown, all five variables are non-stationary at the level with the constant and with the time trend. However, when the first difference was used, the results for all variables showed that they became significant, meaning that they became stationary.

\section{Estimating VAR Model}

The second step is testing the long run relationship among the model variables. Therefore, the Johansen's test (Johansen, 1991) is applied. Specifically, the papers applied the Johansen co-integration test by using trace test and Max-Eigen Value test. The results indicate that, at significance level 5\%, there is no co-integrating equation. Therefore, there is no long-run effect of oil price shocks on manufacturing output. Hence, one cannot apply the error correction model, but one can run the Vector Auto Regressive model VAR.

The VAR model has been used in similar researches as indicated above in the literature review. Besides, the VAR model allows for utilizing the Impulse Response Function as well as the Variance Decomposition, which assess the current and future effects of oil price shocks on the economic variables included in the model. Moreover, the Variance Decomposition analysis will allow for assessing the relative impact of oil price shocks on the volatility of the other variables. The typical VAR model has the following form:

$$
Y_{t}=\alpha+\sum_{i=1}^{p} \xi_{i} Y_{t-i}+\varphi X_{t}+\varepsilon_{t}
$$

where $\boldsymbol{Y}_{\boldsymbol{t}}$ is an $\mathrm{m}^{*} 1$ column vector of market volatility, $\boldsymbol{\alpha}$ is an $\mathrm{m}^{*} 1$ column vector of constants, $\boldsymbol{\xi}_{\mathbf{i}}$ is an 
$\mathrm{m}^{*} \mathrm{~m}$ matrix of coefficients, $\mathbf{X}_{\mathbf{t}}$ is a $\mathrm{q}^{*} 1$ vector of exogenous variables, and represents an $\mathrm{m}^{*} 1$ column vector of unobserved disturbances assumed to be independently and identically distributed (i.i.d.) with $\varepsilon\left(\boldsymbol{\varepsilon}_{\mathbf{t}}=\mathbf{0}\right)$.

\section{VAR Lag Length Order Criteria}

The optimal lag length of the VAR model is (4) according to AIC, SC, and HQ indexes as appearing in Table 3 .

Table 3

VAR Lag Length Order Criteria

\begin{tabular}{lllll}
\hline Lag & LogL & AIC & SC & HQ \\
\hline 0 & -622.28 & 28.51 & 28.71 & 28.58 \\
1 & -434.58 & 21.11 & 22.33 & 21.56 \\
2 & -426.49 & 21.88 & 24.11 & 22.71 \\
3 & -408.54 & 22.20 & 25.45 & 23.40 \\
4 & $-232.6^{*}$ & $15.35^{*}$ & $19.61^{*}$ & $16.93^{*}$ \\
\hline
\end{tabular}

Note. * Indicates lag order selected by the criterion.

LogL: $\log$ likelihood; AIC: Akaike information criterion; SC: Schwarz information criterion and HQ: Hannan — Quinn information.

After determining the optimal lag-length of the VAR models by log-likelihood ratio criterion, and Akaike information criterion, the paper estimates the effect of oil price shocks on all variables, especially the manufacturing sector product in Saudi Arabia during the specified period using the Impulse Response Function.

\section{The Impulse Response Functions}
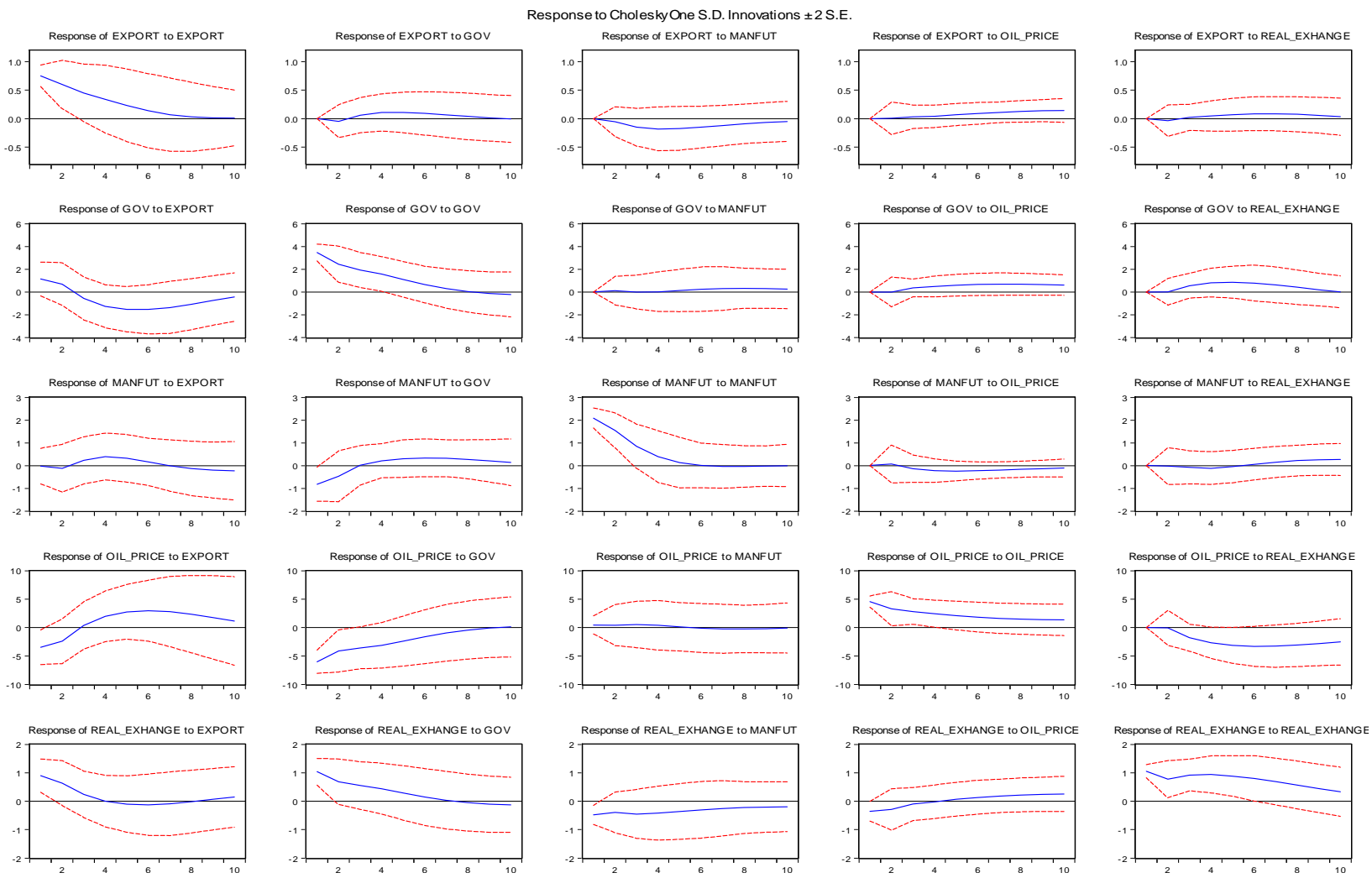

Figure 3. The impulse response functions.

Based on the preceding VAR model, one can identify four impulse responses (illustrated in Figure 3), 
which evaluate the effect of a shock on variations in current or future values of the oil prices and manufacturing sector output and the other variables. Accumulated response to Cholesky one S.D. innovations \pm 2 S.E.

Based on the chart analysis in Figure 3, one can state the following estimations: (1) A $+2 \%$ shock in the oil price level generates almost no effect on the Saudi Arabia manufacturing sector output in during the period of the forecast. The results of VAR estimation supported this result, as the estimation shows that the oil price parameter was non-significant during the period. However, according to the result of the Impulse Response Function and VAR results, oil prices have positive effect on the government spending during the next 10 quarters.

\section{Conclusion}

Investigating the relationship between oil prices and manufacturing sector output has been an issue of interest in recent literature. In spite of the numerous studies and the substantial progresses achieved in developed economies, particularly in the U.S. economy, similar studies and progress in emerging small open economies have not been achieved yet. In this paper, the researchers investigate the effects of oil price changes on the manufacturing sector production in Saudi Arabia. They perform multivariate VAR after adding the control variables appearing in the literature; namely government expenditures, real exchange rate, and industrial exports. The paper finds out that oil price changes have no effect on the manufacturing sector product in Saudi Arabia. The results of VAR estimation and the Impulse Response Function supported the same result, as the estimation shows that the oil price parameter was non-significant during the period of the analysis. However, according to the results of the Impulse Response Function and VAR results, oil price may have an effect on the government spending after 10 periods (quarters), which may lead to an effect on manufacturing output.

\section{References}

Alper, C., \& Torul, O. (2009). Asymmetric effects of oil prices on the manufacturing sector in Turkey. 29th Annual Conference of MEEA in San Francisco, January.

Dizaji, S. F. (2012). The effects of oil shocks on government expenditures and government revenues nexus in Iran, as a developing oil-export based econom. International Institute of Social Studies.Working Pape , 540.

El Anshasy, A. A., \& Bradley, M. D. (2011). Oil prices and the fiscal policy response in oil-exporting countries. UAEU, FBE, Working Paper Series, 2011-08.

Fukunaga, I., Hirakata, N., \& Sudo, N. (2010). The effects of oil price changes on the industry-level production and prices in the U.S. and Japan. NBER, Working Paper, No. 15791.

Garkaz, M., Azma, F., \& Jafari, R. (2012). Relationship between oil revenues and government expenditure, using wavelet analysis method: evidence from Iran. Economics and Finance Review, 2(5), 52-61.

Guidi, F. (2015). The economic effects of oil prices shocks on the UK manufacturing and services sectors. Munich Personal RePEc Archive (MPRA papers).

Hamdi, H., \& Sbia, R. (2013). Dynamic relationships between oil revenues, government spending and economic growth in an oil-dependent economy. Economic Modelling, 35, 118-125.

Johansen, S. (1991). Estimation and hypothesis testing of cointegration vectors in gaussian vector autoregressive models. Econometrica, 59(6), 1551-1580. JSTOR 2938278.

Saudi Arabian Monetary Agency SAMA. Annual Report, Years 2002-2015.

The Economist. (2015). Making it in the desert Kingdom, the electronic print edition. Jan 3rd 2015, http://www. economist.com/news/business/21637399-factory-building-may-not-be-best-way-diversify-economy-making-it-desert

World Development Indicators WDI, World Bank, Years 2002-2015.

Whitley, S., \& Makhijani, S. (2014). Fossil fuel exploration subsidies: Saudi Arabia, oil change international. Country Study. 
Appendix

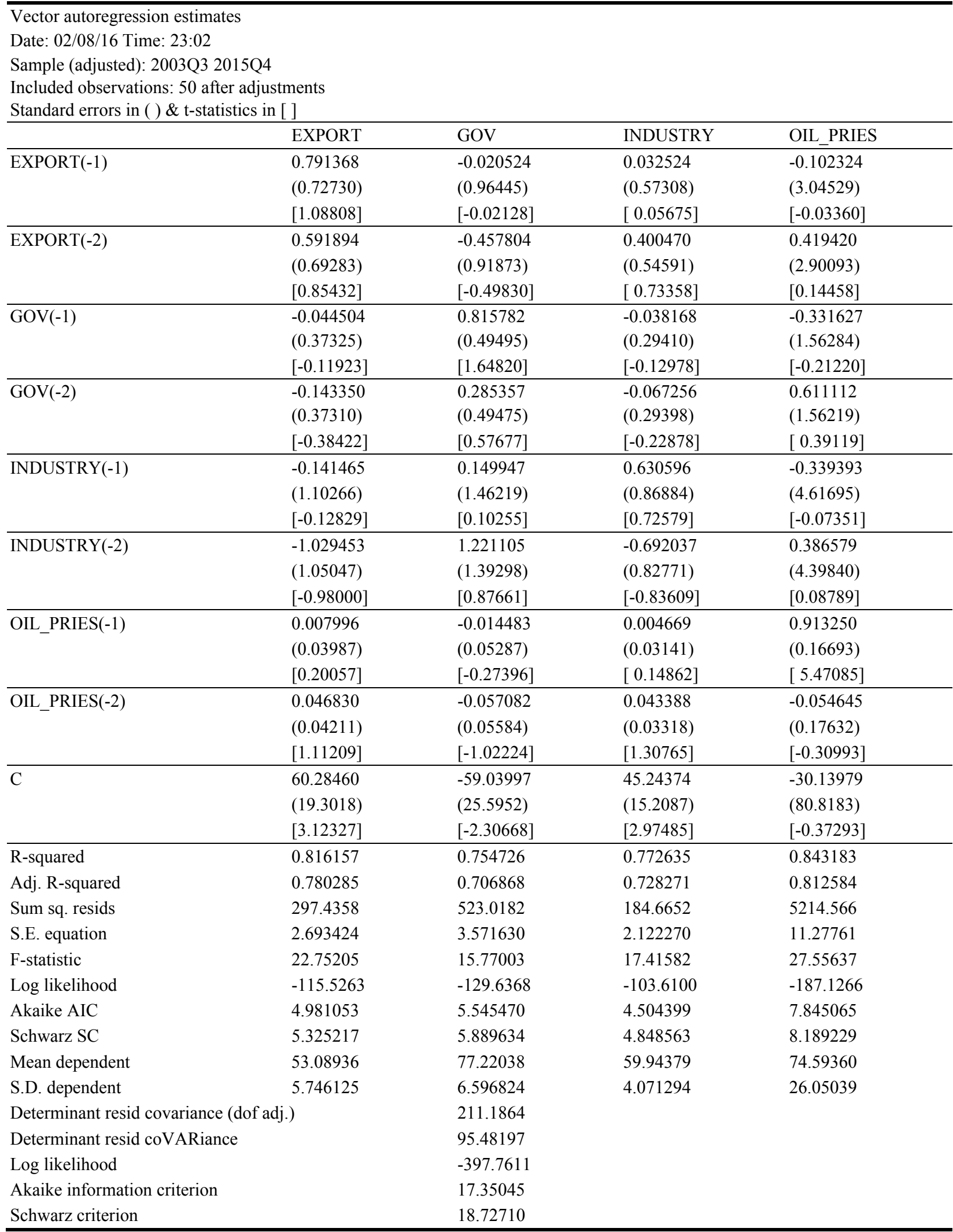




\section{VAR Equations}

EXPORT $=0.791368075696 *$ EXPORT $(-1)+0.591894314474 * \operatorname{EXPORT}(-2)-0.0445042271081 * \mathrm{GOV}(-1)-$ $0.143349600433 * G O V(-2)-0.141465350179 * \operatorname{manuf}(-1)-1.0294529512$ manuf $(-2)+0.00799636914773 *$ OIL_PRIES(-1) + $0.0468298648837 *$ OIL_PRIES(-2) +60.284601835

$$
\mathrm{GOV}=-0.0205243778026 * \operatorname{EXPORT}(-1)-0.457804122515 * \operatorname{EXPORT}(-2)+0.815781809736 * \mathrm{GOV}(-1)+
$$
$0.285357259442 * G O V(-2)+0.149947310276 *$ manuf $(-1)+1.22110452631 *$ Imanuf $(-2)-0.014483176159 *$ OIL_PRIES(-1) $0.0570816422531 *$ OIL_PRIES(-2) - 59.0399676346

Manufat $=0.0325236739807 *$ EXPORT(-1) $+0.400470365344 * \operatorname{EXPORT}(-2)-0.038167878675 * \mathrm{GOV}(-1)-$ $0.0672562279498 * G O V(-2)+0.630595950465 * \operatorname{manuf}(-1)-0.692037057396 * \operatorname{manuf}(-2)+0.00466859720261 *$ OIL_PRIES(-1) $+0.0433881615622 *$ OIL_PRIES(-2) + 45.2437429096

OIL_PRIES $=-0.102323519875 *$ EXPORT $(-1)+0.419420119416 *$ EXPORT $(-2)-0.331627480937 *$ GOV $(-1)+$ $0.611111692213 * \operatorname{GOV}(-2)-0.33939301152 *$ manuf $(-1)+0.386578862988 * \operatorname{manuf}(-2)+0.913250076818 *$ OIL_PRIES(-1) $0.0546453023902 *$ OIL_PRIES(-2) - 30.1397882213

EXPORT Residuals

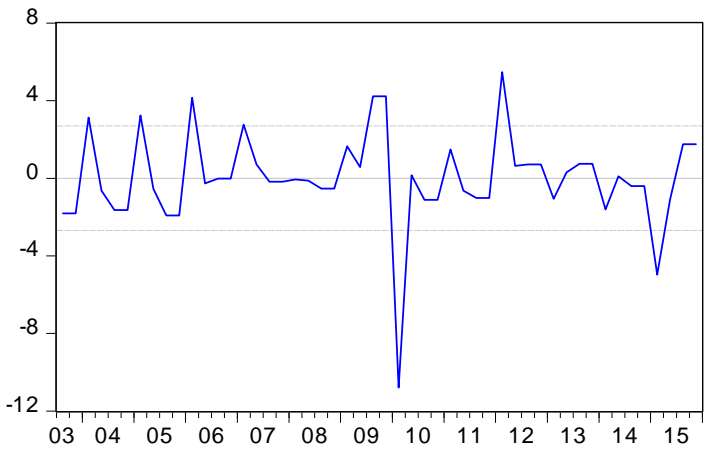

INDUSTRYResiduals

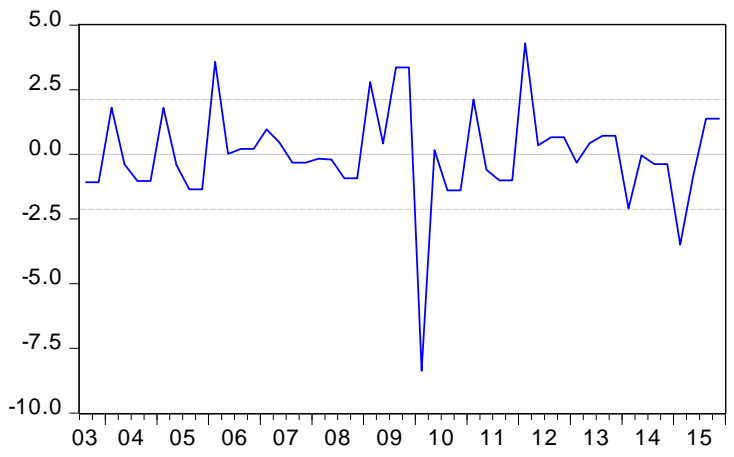

GOV Residuals

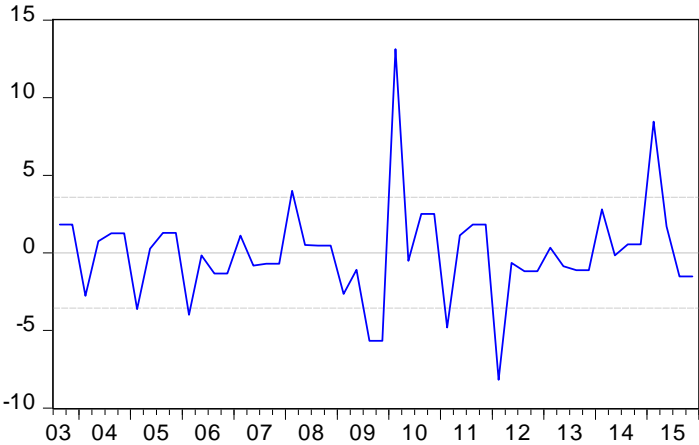

OIL PRIES Residuals

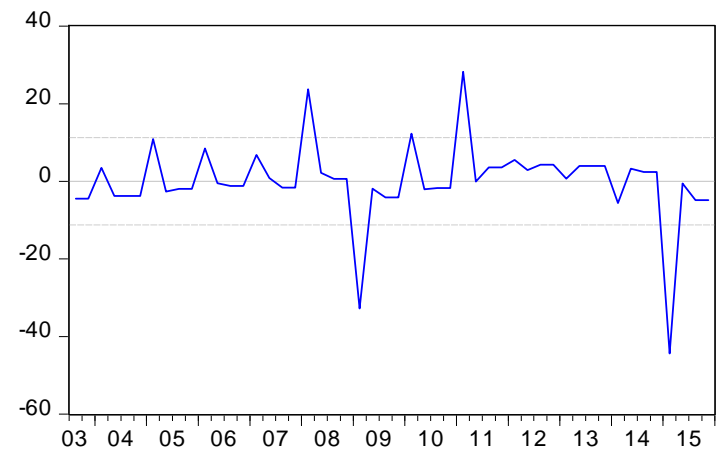

